Please do not remove this page

RMIT

UNIVERSITY

\title{
Urban climate justice: creating sustainable pathways for humans and other species
}

Steele, Wendy; Mata, Luis; Fuenfgeld, Hartmut

https://researchrepository.rmit.edu.au/esploro/outputs/9921862134401341/filesAndLinks?institution=61RMIT_INST\&index=null

Steele, W., Mata, L., \& Fuenfgeld, H. (2015). Urban climate justice: creating sustainable pathways for humans and other species. Current Opinion in Environmental Sustainability, 14, 121-126.

https://doi.org/10.1016/j.cosust.2015.05.004

Document Version: Accepted Manuscript

Published Version: https://doi.org/10.1016/j.cosust.2015.05.004

Repository homepage: https://researchrepository.rmit.edu.au

(c) 2015 Elsevier B.V. All rights reserved.

Downloaded On 2023/04/26 22:25:39 +1000

Please do not remove this page 
Thank you for downloading this document from the RMIT Research Repository.

The RMIT Research Repository is an open access database showcasing the research outputs of RMIT University researchers.

RMIT Research Repository: http://researchbank.rmit.edu.au/

\section{Citation:}

Steele, W, Mata, L and Fuenfgeld, H 2015, 'Urban climate justice: creating sustainable pathways for humans and other species', Current Opinion in Environmental Sustainability, vol. 14, pp. 121-126.

See this record in the RMIT Research Repository at:

https://researchbank.rmit.edu.au/view/rmit:33591

Version: Accepted Manuscript

\section{Copyright Statement:}

(C) 2015 Elsevier B.V. All rights reserved.

\section{Link to Published Version:}

http://dx.doi.org/10.1016/j.cosust.2015.05.004 


\title{
Title: Urban climate justice: creating sustainable pathways for humans and other species
}

\author{
Wendy Steele ${ }^{\mathrm{a} *}$, Luis Mata ${ }^{\mathrm{a}, \mathrm{b}}$ and Hartmut Fuenfgeld ${ }^{\mathrm{a}}$ \\ ${ }^{\mathrm{a}}$ Centre for Urban Research and ${ }^{\mathrm{b}}$ Interdisciplinary Conservation Science Research Group, \\ School of Global, Urban and Studies, RMIT University, 124 La Trobe Street, Melbourne \\ 3000, Victoria, Australia
}

* Corresponding author: Wendy Steele: wendy.steele@rmit.edu.au, phone: + 61399252302

\begin{abstract}
Within the current climate of change (environmental, economic and social) what constitutes 'justice' is continually shifting in relation to vulnerable people, places and species. This is most acute in cities, where the majority of people now live and the need to create new pathways of co-existence between humans and other species has been recognized. The convergence of rapid urbanization and anthropogenic climate change has had disproportionately negative effects on the urban poor and those most marginalized (human and non-human). This paper provides a critical overview of the emergent field of urban climate justice which focuses on the complex links between environmental sustainability, human vulnerability and biodiversity loss in the natural environment. This is an interdisciplinary agenda demanding new forms of sustainability research and practical engagement underpinned by calls for a more integrated approach to eco-social justice principles around human and other species equity in cities.
\end{abstract}

\section{Introduction}

With more than half the world's population now living in urban areas, cities have been described as 'hotbeds of greenhouse gas emissions and vulnerability' [1]. Urban areas are places of concentrations of human activity, and, consequently, they are also places where the causes and impacts of anthropogenic climate change can be located and localised [2,3]. There is little doubt that the way cities will evolve is critical in combating runaway climate change, and their important role is increasingly recognised in the international arena [1]. As the impacts of climate change are progressively felt across the globe, concern is increasing as to their likely unequal distribution.

Cities, due to their concentration of people, assets and infrastructure and their already highly stratified profiles of socio-economic disadvantage and vulnerability, are becoming critical locations for climate justice, a term that highlights the equity implications of climate change and the associated human responses [4-8]. A major concern is that climate change is likely to exacerbate existing social vulnerabilities, and that these effects may be greatest in marginal areas of cities, where, unless supported to do so by third parties, impoverished people have limited means and capacity to respond to climatic events and adapt to anthropogenic environmental change $[2,3]$.

However, as 'urban climate justice' is rising on the agenda of researchers and decisionmakers $[4,5,6]$, its interpretation as both distributive (i.e. the allocation of benefits and burdens) and procedural (i.e. how procedures and practices recognize interests) has been largely confined to the equity implications of climate change on humans. This constraining perspective, which excludes non-human ecological communities and species, is and isn't 
surprising. It is not surprising when considering the very apparent dominance of humans in urban spaces, our ability to 'develop' and transform large stretches of nature into built environments, and the growing disconnect between city dwellers and nature [9]. The narrow focus on 'justice for humans' is surprising, however, when we consider the rapidly growing awareness of the eco-ethics of the rights of nature in the city through for example wild law, earth governance initiatives and earth jurisprudence [10] to the nature of human dependence on vital ecosystem services (e.g. municipal governments striving to create interconnected urban forests that promote biodiversity [11])

In this paper, we argue for the need to move beyond bifurcated approaches to urban climate justice to more explicitly include, alongside a focus on humans, the non-human ecological communities and species that contribute to biodiversity in the city. In reviewing the recent literature on this emerging area of scientific inquiry, we explore the interconnections between human and non-human phenomena of urban climate justice and injustice and outline the emergence of new conceptual and ethical frameworks that seek to guide integrated interdisciplinary research in this key area.

\section{Climate justice in an urbanised world: An equitable response to species vulnerability?}

The combined effects of urbanization and climate change have resulted in disproportionately negative impacts on those in the city that are often already most marginalised and disadvantaged. As The Global Report on Human Settlements Cities and Climate Change [12] highlights, the more affluent in our society are less vulnerable, with the impacts of climate change being felt most by the most marginalized groups, which include the urban poor, children, women and the elderly. Injustice occurs when the most vulnerable communities bear a disproportionate burden of the impacts, often with the least resources or capacity to respond [13,14]. Barnett [15] identifies five key aspects to understanding climate (in)justice:

1. the responsibility for climate change is not equally distributed;

2. climate change will not affect all people equally with some people and groups more vulnerable;

3. this vulnerability is determined by political-economic processes that benefit some more than others;

4. climate change will compound under development because of the processes of disadvantage embedded within the economic status quo; and

5. climate change policies may themselves create unfair outcomes by exacerbating, maintaining or ignoring existing and/or future inequalities (misframing and maladaptation).

Within the built environment, vulnerability to climate change is determined by a community's capacity to anticipate, resist and/or recover from the impacts of major changes such as extreme weather events (e.g. drought, floods, heat waves and fire). For humans this is exacerbated by substandard or badly designed housing, reductions in green space, and exposure to environmental risks (e.g. air and water pollution, insect-borne diseases and heat islands). The negative effects that urbanization has had on humans, however, have also been experienced by a large and wide diversity of other species, including plants [16], insects [17], birds $[16,18]$ and many other non-human taxa [19-21], as rapid urban expansion continues to 
change land use patterns in many parts of the world. Stress factors resulting from urbanization on both humans and other species have been and will continue to be exacerbated by anthropogenic climate change [22-25], but are rarely acknowledged as issues of climate justice within current policy and planning frameworks.

Like vulnerable and marginalised human communities in cities, many non-human species within urban ecosystems are more susceptible than others to the negative impact of climate change. Most vulnerable species possess ecological traits that increase their sensitivity to detrimental impacts [25-27]. For example, Prior and Bowman [28] have predicted the growth of large eucalypt trees to be more vulnerable to high temperatures, which, in a warming world, will impede forest recovery from extreme events and exacerbate the effects of increased drought stress and more frequent fire. Caruso et al. [29] found a widespread rapid reduction in body size of salamanders in response to changes in moisture and temperature, a trend that was greatest in regions experiencing the greatest drying and warming, rising the questions of whether salamander adaptation will be able to keep pace with climate change in the future. Working with jumping plant-lice, Moir et al. [30] have identified insect traits that may increase their vulnerability to co-extinction, highlighting how species with high degree of host-specificity with endangered plants are very likely to follow their host plants into extinction.

Other non-human species are more vulnerable by exposure to external factors $[25,26]$. Atkinson et al. [31], for example, have predicted that increases in mean temperatures could lead to expansion of avian malaria into habitats where cool temperatures currently limit transmission to endemic forest birds. Working with potamodromous fishes, Beatty et al. [32] have shown that anthropogenic-induced regional reductions in annual surface water discharge and stream flow periods will reduce fish spawning habitat availability and connectivity. Gaillard et al. [33] have observed that populations of roe deer grow more slowly when spring is early, indicating that this presently widespread mammal will not be able to cope with increasingly early springs. Studying polar soil invertebrates, Nielsen and Wall [34] have shown that climate amelioration is likely to increase the influx of non-native species, with negative effects on local biodiversity.

Some of these changes will result in detrimental effects to species' fitness and their ability to thrive in specific ecosystems. For many ecosystems, these additional vulnerabilities induced by climate change will be compounded by the direct and indirect effects of urbanization, including but not limited to urban expansion and land use change. Ultimately, however, the most adverse organismal response to urbanization and anthropogenic climate change is extinction $[22,23,35]$, with some authors arguing that the Anthropocene is an era that will witness planet Earth's sixth mass extinction [36]. This will affect both humans and nonhumans creating novel species assemblages under future climatic conditions [37].

We are living in human-induced climate change, and in the age of the Anthropocene this is not something that is just happening to cities but is actively being produced in and by the city through the urbanization process [6]. This disrupts popular understandings around the ambit of urban inequity and vulnerability in ways that challenge the idea and practice of climate justice in cities. It calls for a paradigm shift towards identifying, and considering the compounded impacts of climate change and urbanization on, vulnerable non-human species in all urban climate change responses. 


\section{New directions - rethinking the ambit of climate justice in cities}

In an age in which humans and non-human ecologies and systems interrelate in complex urban assemblages, new directions in the climate justice literature call us to move beyond binary conceptualisations and practices, recognizing that: (i) climate change is a crisis of society as well as the natural environment, wherein the impacts are felt most by the most marginalised segments (both in the human and the non-human realm); (ii) society and nature are simultaneously, mutually and constantly, reconfigured by the ways that urban relations are played out, making it difficult to ascertain the justice implications of climate change without considering society and nature; and, consequently (iii) we must better take into account the complex and dynamic links between human society and the natural environment in the transition to environmentally sustainable futures [4].

Within the climate justice literature there are a number of emergent shifts related to key questions around the 'where' and 'what' of urban climate justice (see Table 1 below). The shifting focus for example includes greater recognition of the urban/city and local scale alongside an ongoing emphasis on climate justice at the international/ national scale between the global North and South [38]. Previously the climate justice literature focused almost exclusively on questions of distributive and inter-generational justice, rights and responsibilities such as polluter pays, fair share and rights-based models (e.g. with regard to development, human and environmental rights) [39]. However, the more recent literature recognizes that these approaches still largely fail to adequately acknowledge the diverse experience of climate risks for both humans and non-humans, the contested nature of many proposed solutions, and the lived practices already occurring and working to create change in cities. In particular the links between humans and non-humans and the inadequate nature of the distribution of benefits and burdens across the species borderline have been highlighted through the climate justice lens [4].

Table 1 New directions in the urban climate justice literature

\begin{tabular}{|l|l|l|}
\hline \multirow{2}{*}{ Where } & Late 20th century focus & Early $\mathbf{2 1}^{\text {st }}$ century shifts to include \\
\hline Who & International/National & Urban/City/local \\
\hline What & $\begin{array}{l}\text { Human society } \\
\text { Nation state and/or Individual }\end{array}$ & $\begin{array}{l}\text { Society }+ \text { nature; human }+ \text { non-human } \\
\text { Community }\end{array}$ \\
\hline How & $\begin{array}{l}\text { Rights, responsibilities, } \\
\text { representation }\end{array}$ & $\begin{array}{l}\text { Recognition and capabilities, 'ecologies of } \\
\text { practice' }\end{array}$ \\
\hline $\begin{array}{l}\text { Technological responses and } \\
\text { solutions }\end{array}$ & $\begin{array}{l}\text { Politics and cultural: the contested and } \\
\text { diverse nature of climate justice responses } \\
\text { Informal mechanisms (community }\end{array}$ \\
\hline & 4 & \\
\hline
\end{tabular}




\begin{tabular}{|l|l|l|}
\hline & $\begin{array}{l}\text { Formal mechanisms (state or } \\
\text { intergovernmental negotiations) }\end{array}$ & activism, NGO's) \\
$\begin{array}{l}\text { Justice in theory, human rights and } \\
\text { polluter pays based models }\end{array}$ & $\begin{array}{l}\text { Hybrid, new ecology, creative } \\
\text { cosmopolitical experiments and transitional } \\
\text { practices }\end{array}$ \\
\hline
\end{tabular}

In addition, a recent turn in the urban climate justice literature has called for expanding the boundaries of urban climate vulnerability and associated responses by focusing on questions related to the 'who' and the 'how' of urban climate justice, interrogating notions of power and participation in climate change responses. Building on the work of urban political ecologists [40,41] and environmental justice scholars [42-44] this involves: greater recognition and engagement with social and natural systems as co-contributors to both the conditions of urban climate resilience and vulnerability; and greater emphasis on how urban climate justice is understood, experimented with and contested in practice [45]. As Schlosberg [39] highlights, how can justice be applied to the very real and growing effects of climate change in cities on the ground?

This has led to calls for better understanding diverse and creative socio-ecological innovation and transitions in practice that recognize and respond to both human and non-human vulnerability to climate change in cities $[38,46,47]$. Understanding how climate justice impacts can be considered through a capabilities framework, for example, helps bridge the gap between climate justice theory and urban climate policy-making through a process of recognizing, mapping and indexing and then prioritizing urban climate justice action across communities and species $[39,48,49]$. Earth jurisprudence and wild law proponents seeks to use earth laws to create a legal identity for ecosystems and species as a means by which to protect the rights of the non-human- nature - through a more earth-centred planning and law system [59].

There is widespread recognition that, in the context of climate change, city administrators and decision-makers need to work across conventional borders to better understand intrinsically coupled natural and social systems and the interactions of human and non-human communities with rapidly changing urban environments. Both privileged and marginalized populations are connected to place and affect each other in relational ways. It is vitally important to find new ways of imagining climate change as an issue of urban justice with ecological, social and cultural dimensions by envisaging climate justice alternatives [56,57].

New critical environmental research highlights an evolving 'ecologies of practice' approach to urban climate justice through a focus on urban-social-natural hybridity and 'cosmopolitics': whereby both human and non-human stories, relations, politics and practices connect to destabilise technocratic responses to anthropogenic climate change [50-52]. In this way urban climate justice engages both the practices and imagination necessary to create a new eco-social urban ethic and sustainable future in a climate of planetary crisis and change $[54,55]$.

\section{Just cities - creating sustainable pathways for humans and other species}

The climate-just city must focus both on the contemporary city's nature and the role of nature in cities in the Anthropocene. Yet a largely separate literature and discourse has evolved in 
which the vulnerabilities of human populations (urban climate justice) and the vulnerability of key elements of biodiversity within ecosystems (urban ecology and conservation science) are artificially divided and responses addressed within disciplinary silos and practices. This is both a conceit and an artifice that is starting to be better recognized within both the academy and policy; an artificial separation that negates the shared context of the earth and thus works to inhibit our capacity to create new pathways of co-existence between humans and other species.

Integrating the complex links between human vulnerability and biodiversity loss in the natural environment will require an interdisciplinary agenda and new forms of sustainability research fundamentally underpinned by an integrated approach to eco-social justice and equity in cities. This is an interdisciplinary agenda not just in rhetoric or theory, but embedded in research and policy approach, thinking and practices around multi-natural alternatives [58]. Current methods for assessing the impacts of climate change on cities need to incorporate both an appraisal of impacts on the natural environment and negotiations of climate justice for humans and non-humans.

An expanded conceptualisation of urban climate justice, based on a truly ecological sense of human-nature interactions, can help devise much needed creative and innovative responses to the global climate crisis. Future research must focus more specifically on how climate justice can inform effective urban climate policy and planning and the implications of the justice lens for urban decision-making and governance processes in climate change. For both humans and other species this is how the pathways to environmental sustainability and urban climate justice will be gained.

\section{Acknowledgements}

WS wishes to acknowledge funding from the Australian Research Council on DECRA project [DE120102428]. LM wishes to acknowledge the support of funding from the Australian Government's national Environmental Research Program (NERP) and the Australian Research Council Centre of Excellence for Environmental Decisions (CEED).

\section{References and recommended reading}

Papers of particular interest, published within the period of review, have been highlighted as:

* of special interest

** of outstanding interest

[1] Romero-Lankao P, Dodman D: Cities in transition: Transforming urban centers from hotbeds of GHG emissions and vulnerability to seedbeds of sustainability and resilience. Curr Opin Env Sust 2011, 3:113-120.

[2] Rosenzweig C, Solecki WD, Hammer SA, Mehrotra S: Urban Climate Change in Context. In Climate Change and Cities: First Assessment Report of the Urban Climate Change Research Network. Edited by Rosenzweig C, Solecki WD, Hammer SA, Mehrotra S. Cambridge University Press; 2011:3-11. 
[3] Gasper R, Blohm A, Ruth M: Social and economic aspects of climate change on the urban environment. Curr Opin Env Sust 2011, 3:150-157.

[4] Steele W, MacCallum D, Byrne J, Houston D: Planning the climate-just city. Int Plan Stud 2012, 17:67-83.

** This paper outlines a conceptual and analytical framework for the 'climate-just city' which focuses on integrating the principles of climate justice and equity into urban planning thinking and practice.

[5] Bulkeley H, Betsill MM: Revisiting the urban politics of climate change. Env Polit 2013, 22:136-154.

[6] Bulkeley H, Carmin J, Castán Broto V, Edwards GAS, Fuller S: Climate justice and global cities: Mapping the emerging discourses. Global Environ Chang 2013, 23:914-925.

** This paper draws on a database of initiatives in 100 global cities to examine how discourses of justice are emerging within urban responses to climate change.

[7] Forsyth T: Climate justice is not just ice. Geoforum 2013, 54:230-232.

[8] Hughes S: Justice in urban climate change adaptation: Criteria and application to Delhi. Ecol Soc 2013, 18:4.

** This paper develops criteria to assess justice in adaptation so that the processes, priorities, and impacts address the needs of the most vulnerable urban populations.

[9] Girardet H: Creating regenerative cities. Routledge; 2014.

[10] Maloney M, Burdon P (Eds): Wild law in practice. Routledge; 2014.

[11] City of Melbourne: Urban forest strategy - Making a great city greener (2012-2032). City of Melbourne; 2012.

[12] United Nations: Cities and climate change: Policy directions, global report on human settlements. United Nations Human Settlements Program; 2011.

[13] Paavola J, Adger WN: Fair adaptation to climate change. Ecol Econ 2006, 56:594-609.

[14] Wilson SM, Richard R, Joseph L, Williams E: Climate change, environmental justice, and vulnerability: An exploratory spatial analysis. Environ Justice 2010, 3:13-19.

[15] Barnett J: Climate change, insecurity and injustice. In Fairness to Adaptation to Climate Change. Edited by Adger W, Paavola J, Huq S, Mace M. Massachusetts Institute of Technology; 2006.

[16] Aronson M, La Sorte F, Nilon C, Katti M, Goddard M, Lepczyk C, Warren P, Williams $\mathrm{N}$, Cilliers S, Clarkson B et al.: A global analysis of the impacts of urbanization on birds and plant diversity reveals key anthropogenic drivers. Proc $R$ Soc B 2014, 10.1098/rspb.2013.3330.

** The authors compile and analyse the largest global dataset of plants and birds in cities. They show that, although the majority of the species studied are native, the density of plant 
and bird species has declined substantially, with only $25 \%$ of native plant and $8 \%$ of native bird species being currently present in cities compared with estimates of non-urban densities.

[17] Mata L, Goula M, Hahs AK: Conserving insect assemblages in urban landscapes: accounting for species-specific responses and imperfect detection. J Insect Conserv 2014, 18:885-894.

[18] Sushinsky J, Rhodes J, Possingham H, Gill T, Fuller R: How should we grow cities to minimize their biodiversity impacts? Glob Change Biol 2013, 19:401-410.

[19] McKinney M: Effects of urbanization on species richness: a review of plants and animals. Urban Ecol 2008, 11:161-176.

[20] Luck G, Smallbone L: Species diversity and urbanization: patterns, drivers and implications. In Urban ecology. Edited by Gaston K. Cambridge University Press; 2010:88119.

[21] Faeth SH, Bang C, Saari S: Urban biodiversity: patterns and mechanisms. Ann NY Acad Sci 2011, 1223:69-81.

[22] Thomas CD, Cameron A, Green RE, Bakkenes M, Beaumont LJ, Collingham YC, Erasmus B, Ferreira de Siquiera M, Grainger A, Hannah L et al.: Extinction risk from climate change. Nature 2004, 427:145-148.

[23] Parmesan C: Ecological and Evolutionary Responses to Recent Climate Change. Annu Rev Ecol Evol Syst 2006, 37:637-669.

[24] Mooney H, Larigauderie A, Cesario M, Elmqvist T, Hoegh-Guldberg O, Lavorel S, Mace GM, Palmer M, Scholes R, Yahara T: Biodiversity, climate change, and ecosystem services. Curr Opin Env Sust 2009, 1:46-54.

[25] Pacifici M, Foden WB, Visconti P, Watson JEM, Butchart SHM, Kovacs KM, Scheffers BR, Hole DG, Martin TG, Akçakaya HR et al:: Assessing species vulnerability to climate change. Nature Clim Change 2015, 5:215-225.

[26] Williams SE, Shoo LP, Isaac JL, Hoffmann A, Langham G: Towards an integrated framework for assessing the vulnerability of species to climate change. PLoS Biol 2008, 6:2621-2626.

[27] Huey R, Kearney M, Krockenberger A, Holtum J, Jess M, Williams S: Predicting organismal vulnerability to climate warming: roles of behaviour, physiology and adaptation. Phil Trans R Soc B 2012, 10.1098/rstb.2012.0005.

[28] Prior L, Bowman D: Big eucalypts grow more slowly in a warm climate: evidence of an interaction between tree size and temperature. Glob Change Biol 2014, 20:2793-2799.

[29] Caruso N, Sears M, Adams D, Lips K: Widespread rapid reductions in body size of adult salamanders in response to climate change. Glob Change Biol 2014, 20:1751-1759.

[30] Moir M, Hughes L, Vesk P, Leng M: Which host-dependent insects are most prone to coextinction under changed climates? Ecol Evol 2014, 4:1295-1312. 
* The authors assess how climate change may act synergistically to accelerate rates of coextinction. They present a synthesis of the literature and propose methods to assess the potential risks that climate change poses on dependant species.

[31] Atkinson C, Utzurrum R, Lapointe D, Camp R, Crampton L, Foster J, Giambelluca T: Changing climate and the altitudinal range of avian malaria in the Hawaiian Islands - an ongoing conservation crisis on the island of Kaua'i. Glob Change Biol 2014, 20:2426-2436.

[32] Beatty S, Morgan D, Lymbery A: Implications of climate change for potamodromous fishes. Glob Change Biol 2014, 20:1794-1807.

[33] Gaillard J, Hewison M, Klein F, Plard F, Douhard M, Davison R, Bonenfant C: How does climate change influence demographic processes of widespread species? Lessons from the comparative analysis of contrasted populations of roe deer. Ecol Lett 2013, 16:48-57.

[34] Nielsen U, Wall D: The future of soil invertebrate communities in polar regions: different climate change responses in the Arctic and Antarctic? Ecol Lett 2013, 16:409419.

[35] Bellard C, Bertelmeier C, Leadley P, Thuiller W, Courchamp F: Impacts of climate change on the future of biodiversity. Ecol Lett 2012, 15:365-377.

[36] Barnosky A, Matzke N, Tomiya S, Wogan G, Swartz B, Quental T, Marshall C, McGuire J, Lindsey E, Maguire K, Mersey B, Ferrer E: Has the Earth's sixth mass extinction already arrived? Nature 2011, 471:51-57.

[37] Young K: Biogeography of the Anthropocene: Novel species assemblages. Prog Phys Geog 2014, 38:664-673.

* This paper focuses on how humans have altered the cycles of Earth, with many implications for how the study of the distributions of organisms should change. It also highlights that new approaches are needed for understanding how new groupings of species will function ecologically under future climatic and landscape conditions.

[38] Bulkeley H, Edwards G AS, Fuller S: Contesting climate justice in the city: Examining politics and practice in urban climate change experiments. Glob Environ Chang 2014, 25:31-40.

** This paper focuses on how climate justice is being pursued at the urban scale and offers an analytical and conceptual tool involving a three-dimensional pyramid of distributions, procedures, rights, responsibilities and recognition to interrogate climate practices.

[39] Schlosberg D: Climate justice and capabilities: A framework for adaptation policy. Ethics Int Aff 2012, 26:445-461.

** This paper outlines a capabilities approach to climate justice that recognizes that justice depends on a revised understanding of the relationship between human beings and the nonhuman world.

[40] Keil R: Urban political ecology. Urban Geogr 2003, 26:640-651.

[41] Swyngedouw E, Heynen N: Urban political ecology, justice and the politics of scale. Antipode 2003, 35: 898-918. 
[42] Agyeman J: Introducing just sustainabilities: Policy, planning and practice. Zed Books; 2013.

[43] Byrne J: Environmental justice. In Encyclopedia of Geography. Edited by Solomon BD. Thousand Oaks; 2010.

[44] Schlosberg D: Theorising environmental justice: The expanding sphere of a discourse. Environ Polit 2013, 22:37-55.

[45] Schlosberg D, Collins LB: From environmental to climate justice: Climate change and the discourse of environmental justice. WIREs Clim Change 2014, DOI: 10.1002/wcc.275.

** This paper builds on environmental justice thinking and practices to focus on the range of principles and demands of grassroots climate justice movements, ideas for just adaptation to climate change.

[46] Broto VC, Bulkeley H: Maintaining climate change experiments: Urban political ecology and the everyday reconfiguration of urban infrastructure. Int $J$ Urban Reg Res 2013, 6:1943-1948.

* In this paper the focus is on urban climate change experiments that seek to reconfigure urban sociotechnical systems to achieve low-carbon and resilient cities.

[47] Broto VC, Bulkeley $\mathrm{H}$ : A survey of urban climate change experiments in 100 cities. Glob Environ Chang 2013, 23:92-102.

* This paper argues that cities are key sites where climate change is being addressed and there is a mix of actors, settings, governance arrangements and technologies involved in the governance of climate change in cities in different parts of the world.

[48] Nussbaum M: Creating capabilities: The human development approach. Harvard University Press; 2011.

[49] Sen A: The Idea of Justice. Harvard University Press; 2009.

[50] Hulme M: Cosmopolitan climates: Hybridity, foresight and meaning. Theor Cult Soc 2010, 27:267-276.

[51] Stengers I: Cosmopolitics I, II. Translated by Bononno R. 2010. University of Minnesota Press; 2010.

[52] Houston D, MacCallum D, Steele W: Climate Cosmopolitics. Beyond Utopia Conference, Santa Barbara 2012.

[53] Agyeman J: Entering Cosmopolis: Crossingover, hybridity, conciliation and the intercultural city ecosystem. Minding Nature 2014, 7:20-25.

[54] Houston D: Crisis and resilience: Cultural methodologies for environmental sustainability and justice. Continuum 2008, 22:179-190.

[55] Yusoff K, Gabrys J: Climate change and the imagination. WIREs Clim Change 2011, 2:516-534. 
[56] Davis M: Who will build the ark? New Left Rev 2010, 61:29-46.

[57] MacCallum D, Byrne J, Steele W: Whither justice? An analysis of climate change responses from South East Queensland, Australia. Environ Plann C 2014, 32:70-92.

[58] Lorimer J: Multinatural geographies for the Anthropocene. Prog Hum Geogr 2012, 36:593-612.

[59] Pelizzon A: Transitional justice and ecological jurisprudence in the midst of an ever-changing climate. In Current Issues in Transitional Justice. Edited by Szablewska N, Bachmann SD. Springer International Publishing; 2015: 317-338.

* The focus of this paper is to challenge the removal of society from nature and instead develop 'multinatural' alternatives draw together work in the social and natural sciences to present an interdisciplinary biogeography for conservation in the Anthropocene. 